\title{
Standardization of drying techniques for hybrid tea rose variety, Valencia
}

\author{
Lalhruaitluangi, Chhungpuii Khawlhring* \\ Department of Horticulture, Aromatic and Medicinal Plants, Mizoram University, Aizawl 796004, India
}

\begin{abstract}
The present experiment was carried out to standardize suitable drying techniques for hybrid tea rose variety "Valencia". Two types of desiccants viz., silica gel and boric acid were used as embedding materials for drying, and the flowers were dried in hot air oven with different temperature and time combinations such as $40^{\circ} \mathrm{C}$ for 24 hours and 48 hours, $45^{\circ} \mathrm{C}$ for 24 hours and 48 hours, $50^{\circ} \mathrm{C}$ for 24 hours and 48 hours, $55^{\circ} \mathrm{C}$ for 24 hours and 48 hours, $60^{\circ} \mathrm{C}$ for 24 hours and 48 hours. Different observations were taken such as fresh and dry weight of flowers and hence moisture loss percentage calculated, petal diameter before and after drying were taken and hence petal shrinkage was determined. Sensory evaluations such as flower colour, shape, texture and overall acceptability was also determined. Results show that maximum moisture loss percentage $(86.44 \%)$ was obtained in flowers embedded with silica gel and dried at $60^{\circ} \mathrm{C}$ for 48 hours; largest difference between petal diameter of fresh and dry flowers, and also maximum petal shrinkage of $14.27 \%$ occurred in those embedded with silica gel and dried at $60^{\circ} \mathrm{C}$ for 48 hours, whereas best score in sensory evaluations in terms of flower colour, flower shape, flower texture and overall acceptability were obtained with rose flowers embedded in silica gel and drying at $50^{\circ} \mathrm{C}$ for 48 hours.
\end{abstract}

Key words: Rose drying; hot air oven; embedding materials.

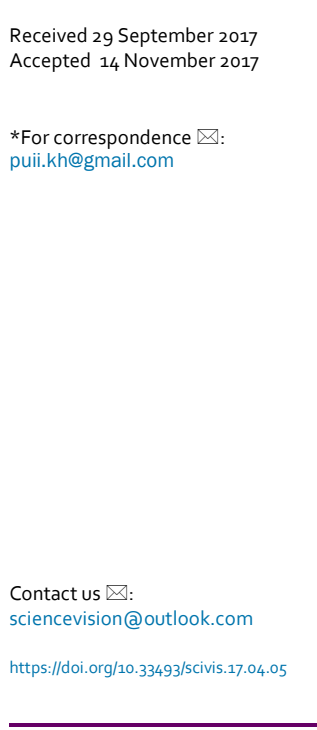

\section{Introduction}

In India, flowers are grown mainly for cut flower and loose flower purposes. Rose is one of the most beautiful flowers possessing scope for various uses in the form of fresh and dried flowers, and it is universally accepted as the 'Queen of flowers'. Fresh rose flowers are highly perishable and delicate in nature, but they can be dried, preserved and processed to retain their beauty. ${ }^{1}$ Drying of flowers have been practiced and perfected over the centuries, and the use of dried flowers has made it possible to enjoy their beauty for several years. Dried flowers are long lasting, can be used several times and also meet the decorative demand throughout the year. ${ }^{2}$ Dried ornamental plant parts are generally less expensive and are sought for their everlasting and attractive appearance. ${ }^{3}$ Various methods of drying like air drying, sun drying, oven and microwave oven drying, freeze drying and embedded drying can be used ${ }^{4,5}$ Hot air and microwave oven drying provides faster drying and also helps to improve the quality of dry flowers. ${ }^{6}$ Dutchrose flowers can be dried at $40^{\circ} \mathrm{C}$ by embedding in silica gel and yet retains good colour, 
texture and appearance. The flowers and foliage for drying are to be embedded carefully in desiccants such as sand or silica gel, ${ }^{8}$ borax and alum ${ }^{9}$ to avoid shrinkage and other morphological changes. ${ }^{2,7}$

Considering the potential of roses in the dry flower trade, an experiment was conducted to standardize optimum temperature and time of drying and also to study the effects of embedding materials of silica gel and boric acid for obtaining better quality rose flowers.

\section{Materials and Methods}

The experiment was conducted in the laboratory of the Department of Horticulture, Aromatic and Medicinal Plants, Mizoram University during April 2017. A hybrid tea rose of variety 'Valencia' having uniform quality was used, and the stems were trimmed to uniform length of $1 \mathrm{~cm}$, and treatments were imposed immediately. Two types of embedding materials i.e., silica gel (S) of Activa Products Inc. Marshall China and also boric acid (B) of HiMedia Lab. Pvt. Ltd. were used for embedding treatments. The embedded flowers were then exposed to different combinations of temperature and time durations $\left(\mathrm{T}_{1}: 40^{\circ} \mathrm{C}\right.$ for
24 hours, $\mathrm{T}_{2}: 40^{\circ} \mathrm{C}$ for 48 hours, $\mathrm{T}_{3}: 45^{\circ} \mathrm{C}$ for 24 hours, $\mathrm{T}_{4}: 45^{\circ} \mathrm{C}$ for 48 hours, $\mathrm{T}_{5}: 50^{\circ} \mathrm{C}$ for 24 hours, $\mathrm{T}_{6}: 50^{\circ} \mathrm{C}$ for 48 hours, $\mathrm{T}_{7}$ : $55^{\circ} \mathrm{C}$ for 24 hours, $\mathrm{T}_{8}: 55^{\circ} \mathrm{C}$ for 48 hours, $\mathrm{T}_{9}: 60^{\circ} \mathrm{C}$ for 24 hours, $\mathrm{T}_{10}: 60^{\circ} \mathrm{C}$ for 48 hours) in hot air oven for drying, and the experiment was set up by using the Completely Randomized Design (CRD). Fresh weight and dry weight of flowers were taken and moisture loss (\%) was thus calculated, diameter of flowers were also taken before and after drying and thus the extend of petal shrinkage determined, and sensory evaluations such as colour, shape, texture and overall acceptability of the flowers were determined by a panel of five judges giving a score ranging from 0 to 4.0, and 4.0 being the highest score. The data obtained were then analyzed statistically by following the standard procedure for analysis.

\section{Results and discussion}

Flower weight: Significant difference was observed in dry weight of flowers and moisture loss percentage as affected by embedding materials and also by drying temperature and time combinations as shown in Table 1. In general, embedding with silica gel showed better mois-

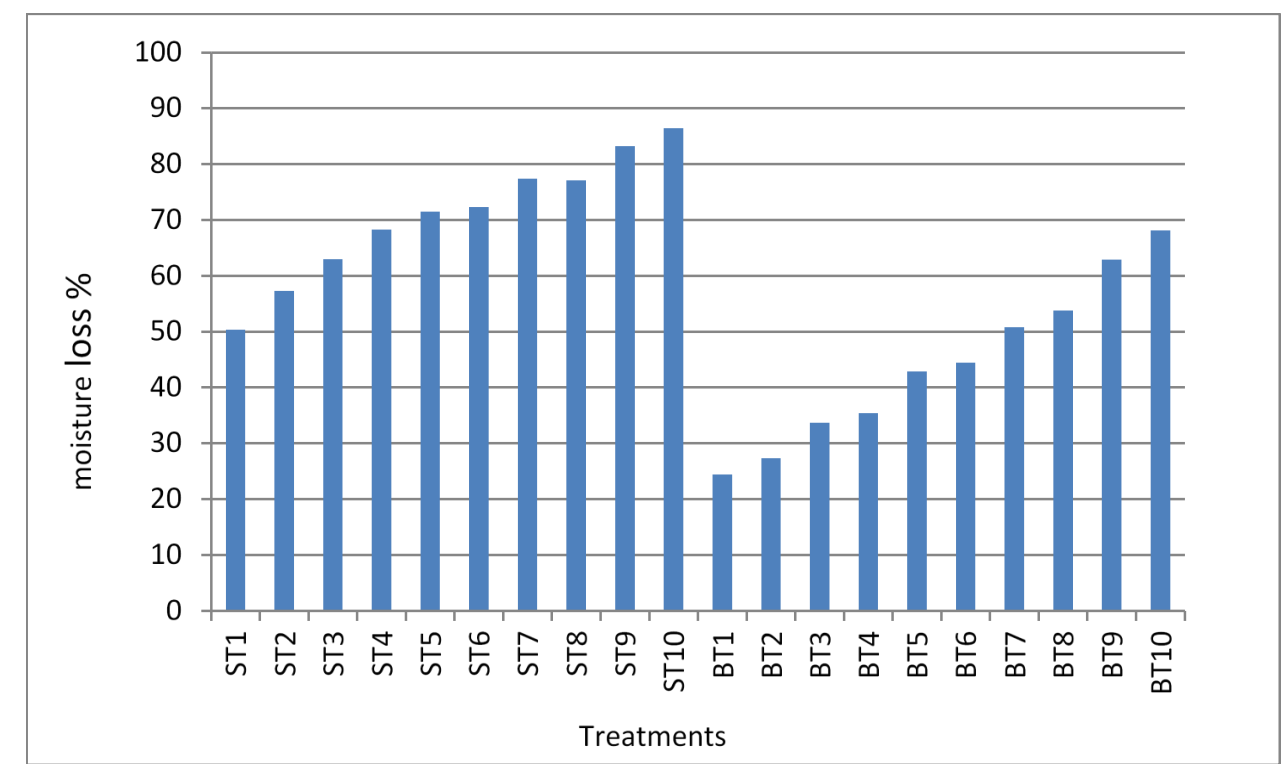

Figure 1 | Percentage moisture loss of rose flowers after different drying treatments. 
Table 1 | Weight (gm) and moisture loss (\%) of rose flowers with different drying treatments.

\begin{tabular}{lccc}
$\begin{array}{l}\text { Treat- } \\
\text { ments }\end{array}$ & $\begin{array}{c}\text { Fresh weight } \\
\text { (gm) }\end{array}$ & $\begin{array}{c}\text { Dry weight } \\
\text { (gm) }\end{array}$ & $\begin{array}{c}\text { Moisture loss } \\
\text { (\%) }\end{array}$ \\
\hline ST1 & 11.44 & 5.75 & 50.36 \\
\hline ST2 & 11.63 & 5 & 57.33 \\
\hline ST3 & 13.91 & 5 & 62.94 \\
\hline ST4 & 10.28 & 3.24 & 68.31 \\
\hline ST5 & 10.68 & 2.88 & 71.5 \\
\hline ST6 & 11.46 & 3.15 & 72.32 \\
\hline ST7 & 12.4 & 2.82 & 77.41 \\
\hline ST8 & 10.54 & 2.3 & 77.11 \\
\hline ST9 & 14.76 & 2.6 & 83.24 \\
\hline ST10 & 13.25 & 1.8 & 86.44 \\
\hline BT1 & 11.02 & 8.31 & 24.41 \\
\hline BT2 & 10.35 & 7.57 & 27.31 \\
\hline BT3 & 11.29 & 7.48 & 33.72 \\
\hline BT4 & 8.85 & 5.72 & 35.4 \\
\hline BT5 & 12.91 & 7.34 & 42.86 \\
\hline BT6 & 13.41 & 7.44 & 44.46 \\
\hline BT7 & 13.45 & 6.6 & 50.82 \\
\hline BT8 & 11.39 & 5.29 & 53.77 \\
\hline BT9 & 10.61 & 3.68 & 62.92 \\
\hline BT10 & 12.41 & 3.93 & 68.11 \\
\hline SEM & 1.14 & 0.64 & 3.78 \\
\hline CD 0.05 & P=NS & P $=0.58 *$ & P $3.42^{*}$ \\
& T=NS & T=1.30* & T=7.65* \\
\hline & PxT=NS & PxT=NS & PxT=NS \\
\hline
\end{tabular}

$\mathrm{P}=$ Embedding; $\mathrm{T}=$ Temperature and time combinations; NS = Not Significant; * = Highly significant

ture loss percent as compared to embedding with boric acid under varying temperature and time combinations (Fig. 1). Temperature also played a significant role, in which higher temperature resulted in lighter dry weight and higher moisture loss percentage. Also flowers dried at 48 hours showed greater loss percentage as compared to drying at 24 hours, even with varying temperatures and also embedding with both silica gel and boric acid. Among all the treatments, maximum dry weight $(8.31 \mathrm{gm})$ coupled with minimum moisture loss percentage (24.41\%) was observed in flowers embedded with
Table 2 | Petal diameter and shrinkage of rose flowers with different drying treatments.

\begin{tabular}{|c|c|c|c|}
\hline $\begin{array}{l}\text { Treat- } \\
\text { ments }\end{array}$ & $\begin{array}{c}\text { Fresh Petal } \\
\text { diameter }(\mathrm{mm})\end{array}$ & $\begin{array}{c}\text { Dry Petal } \\
\text { diameter }(\mathrm{mm})\end{array}$ & $\begin{array}{c}\text { Petal } \\
\text { shrinkage (\%) }\end{array}$ \\
\hline ST1 & 40 & 36.67 & 8.27 \\
\hline $\mathrm{ST} 2$ & 38.33 & 35 & 8.62 \\
\hline ST3 & 42.67 & 38.67 & 9.37 \\
\hline ST4 & 46.67 & 42 & 9.98 \\
\hline ST5 & 42 & 37.67 & 10.37 \\
\hline ST6 & 43 & 38.33 & 10.83 \\
\hline ST7 & 44.33 & 39.33 & 11.29 \\
\hline ST8 & 41 & 36 & 12.26 \\
\hline ST9 & 37.67 & 33 & 12.54 \\
\hline ST10 & 39.33 & 33.67 & 14.27 \\
\hline BT1 & 36 & 33 & 8.31 \\
\hline $\mathrm{BT} 2$ & 37.33 & 34 & 8.88 \\
\hline BT3 & 45 & 40.33 & 10.35 \\
\hline BT4 & 40.33 & 36 & 10.75 \\
\hline BT5 & 43.33 & 38.67 & 10.75 \\
\hline BT6 & 44.67 & 39.67 & 11.12 \\
\hline BT7 & 45.67 & 40.33 & 11.59 \\
\hline BT8 & 43.67 & 38.33 & 12.26 \\
\hline BT9 & 37.33 & 32.67 & 12.52 \\
\hline BT10 & 38 & 33 & 13 \\
\hline SEM & 2.92 & 2.59 & 0.49 \\
\hline \multirow[t]{3}{*}{$\mathrm{CD}_{0.05}$} & $\mathrm{P}=\mathrm{NS}$ & $\mathrm{P}=\mathrm{NS}$ & $\mathrm{P}=\mathrm{NS}$ \\
\hline & $\mathrm{T}=\mathrm{NS}$ & $\mathrm{T}=5.23^{*}$ & $\mathrm{~T}=0.98^{*}$ \\
\hline & $\mathrm{PxT}=\mathrm{NS}$ & $\mathrm{PXT}=\mathrm{NS}$ & $\mathrm{PXT}=\mathrm{NS}$ \\
\hline
\end{tabular}

boric acid and dried at $40^{\circ} \mathrm{C}$ for 24 hours $\left(\mathrm{BT}_{1}\right)$, whereas minimum dry weight $(1.80 \mathrm{gm})$ and maximum moisture loss percentage (86.44\%) was obtained in flowers embedded with silica gel and dried at $60^{\circ} \mathrm{C}$ for 48 hours $\left(\mathrm{ST}_{10}\right)$. This was followed by $\mathrm{ST}_{9}$ (silica gel embedding and drying at $60^{\circ} \mathrm{C}$ for 24 hours), $\mathrm{ST}_{8}$ (silica gel embedding and drying at $55^{\circ} \mathrm{C}$ for 48 hours), $\mathrm{ST}_{7}$ (silica gel embedding and drying at $55^{\circ} \mathrm{C}$ for 24 hours), $\mathrm{ST}_{6}$ (silica gel embedding and drying at $50^{\circ} \mathrm{C}$ for 48 hours) and so on, with the lower temperature and time yielding lesser moisture loss. Moisture content in dried flower influences longevity and 
is inversely proportional to longevity ${ }^{10}$ and hence those treatments with maximum moisture loss are expected to have more longevity, which is a desirable character for dried flowers. on the other hand, excessive drying also may result in petal shedding during handling ${ }^{3}$ and drying below $8 \%$ moisture content showed shedding effect.

Petal diameter/shrinkage: There was significant difference in diameter of dry petal and also petal shrinkage due to various temperature and time combinations, whereas the use of silica gel and boric acid show no significant effect (Table 2). Largest difference between petal diameter of fresh and dry flowers, and also maximum petal shrinkage of $14.27 \%$ occurred in those embedded with silica gel and dried at $60^{\circ} \mathrm{C}$ for 48 hours $\left(\mathrm{ST}_{10}\right)$, followed by $\mathrm{ST}_{9}, \mathrm{ST}_{8} \mathrm{ST}_{7}, \mathrm{ST}_{6}$ and so on. On the other hand, least difference in petal diameter between fresh and dried flowers, and also minimum petal shrinkage of $8.27 \%$ occurred in those flowers embedded with silica gel and dried at $40^{\circ} \mathrm{C}$ for 24 hours $\left(\mathrm{ST}_{1}\right)$. This shows that petal shrinkage was more with increased drying temperature and also time, and petal diameter was retained better with lower drying temperature and also drying time.

Sensory evaluation: There is significant effect of embedding materials and various temperature and time combinations on the sensory evaluation such as colours, shape, texture and overall acceptability of rose flowers after drying (Table 3). Embedding with silica gel gave better score on all the sensory evaluations as compared to embedding with boric acid under similar drying temperature and time combinations. Embedding in silica gel was perhaps the easiest and best method of embedded drying in flowers,$^{10}$ while boric acid was also reported to be a good embedding material for drying of several flowers. ${ }^{2}$ Best colour score of 3.8 was obtained with $\mathrm{ST}_{6}$ (silica gel embedding and drying at $50^{\circ} \mathrm{C}$ for 48 hours) among all the treatment combinations, followed by $\mathrm{ST}_{7}$ (3.73 score), $\mathrm{ST}_{5}$ and $\mathrm{ST}_{8}$ (both scored 3.61) and these treatments are within a temperature of $50^{\circ} \mathrm{C}$ to $55^{\circ} \mathrm{C}$. Among the boric acid embedded flowers, $\mathrm{BT}_{6}$ (drying at $50^{\circ} \mathrm{C}$ for 48 hours) give best score of 2.87 .
Table 3 | Sensory evaluation score of rose flowers with different drying treatments.

\begin{tabular}{|c|c|c|c|c|}
\hline $\begin{array}{l}\text { Treat- } \\
\text { ments }\end{array}$ & Colour & Shape & Texture & $\begin{array}{c}\text { Overall } \\
\text { accepta- } \\
\text { bility }\end{array}$ \\
\hline ST1 & 1.27 & 1.6 & 1.27 & 1.41 \\
\hline $\mathrm{ST} 2$ & 1.56 & 1.79 & 1.27 & 1.56 \\
\hline ST3 & 2.2 & 2.49 & 2.36 & 2.41 \\
\hline ST4 & 2.36 & 2.91 & 2.74 & 2.68 \\
\hline ST5 & 3.61 & 3.28 & 3.66 & 3.41 \\
\hline ST6 & 3.8 & 3.34 & 3.73 & 3.66 \\
\hline ST7 & 3.73 & 3.08 & 3.61 & 3.41 \\
\hline ST8 & 3.61 & 2.8 & 3.32 & 3.32 \\
\hline ST9 & 2.2 & 2.32 & 2.36 & 2.26 \\
\hline ST10 & 1.87 & 2 & 2.26 & 2 \\
\hline BT1 & 0.54 & 0.64 & 0.33 & 0.46 \\
\hline $\mathrm{BT} 2$ & 0.54 & 0.48 & 0.48 & 0.46 \\
\hline BT3 & 1.27 & 0.83 & 1.43 & 1.16 \\
\hline BT4 & 1.56 & 1 & 1.56 & 1.27 \\
\hline BT5 & 2.36 & 2.61 & 2.98 & 2.74 \\
\hline BT6 & 2.87 & 2.91 & 3.32 & 2.8 \\
\hline BT7 & 2.26 & 1.79 & 2.2 & 2.14 \\
\hline BT8 & 2.26 & 1.6 & 2 & 1.97 \\
\hline BT9 & 1.87 & 1.6 & 1.27 & 1.56 \\
\hline BT10 & 1.56 & 1.41 & 1 & 1.27 \\
\hline SEM & 0.11 & 0.09 & 0.1 & 0.08 \\
\hline$C D_{0.05}$ & $\begin{array}{c}\mathrm{P}=0.10^{*} \\
\mathrm{~T}=0.22^{*} \\
\mathrm{PxT}=0.31^{*}\end{array}$ & $\begin{array}{c}\mathrm{P}=0.08^{*} \\
\mathrm{~T}=0.18^{*} \\
\mathrm{PxT}=0.26 *\end{array}$ & $\begin{array}{c}\mathrm{P}=0.09 * \\
\mathrm{~T}=0.20^{*} \\
\mathrm{PxT}=0.28 *\end{array}$ & $\begin{array}{c}\mathrm{P}=0.07 * \\
\mathrm{~T}=0.15^{*} \\
\mathrm{PxT}=0.22 *\end{array}$ \\
\hline
\end{tabular}

Best score of flower shape (3.34) was again obtained with $\mathrm{ST}_{6}$ followed by $\mathrm{ST}_{5}$ and $\mathrm{ST}_{7}$ while $\mathrm{BT}_{6}$ resulted in best score among the boric acid treatments. Again, best score for flower texture (3.73) were obtained with $\mathrm{ST}_{6}$ among all the treatment combinations followed by $\mathrm{ST}_{5}$ and $\mathrm{ST}_{7}$ whereas among the boric acid embedded flowers, $\mathrm{BT}_{6}$ showed best result followed by $\mathrm{BT}_{5}$ (drying at $50^{\circ} \mathrm{C}$ for 24 hours).

The score on overall acceptability also showed a similar pattern, in which best score of 3.66 was obtained with $\mathrm{ST}_{6}$ followed by $\mathrm{ST}_{5}$ and 
$\mathrm{ST}_{7}$ scoring 3.41 each, and again among the boric acid embedded flowers, $\mathrm{BT}_{6}$ showed maximum score of 2.8 followed by $\mathrm{BT}_{5}$

From the present study we observe that maximum moisture loss and hence effective drying of rose flowers and also maximum petal shrinkage during drying are observed in $\mathrm{ST}_{10}$ (flowers embedded with silica gel and dried at $60^{\circ} \mathrm{C}$ for 48 hours), whereas best score in sensory evaluations in terms of flower colour, flower shape, flower texture and overall acceptability were obtained with $\mathrm{ST}_{6}$ (silica gel embedding and drying at $50^{\circ} \mathrm{C}$ for 48 hours) followed by $\mathrm{ST}_{5}$ and $\mathrm{ST}_{7}$ among all other treatment combinations. Among the boric acid embedded flowers, $\mathrm{BT}_{6}$ (drying at $50^{\circ} \mathrm{C}$ for 48 hours) gave best score of flower colour, shape, texture and overall acceptability. Hence considering the quality of dried flowers yielded, among the various temperature and drying time combinations tried in the present experiment, drying at $50^{\circ} \mathrm{C}$ for 48 hours is found to be the recommended drying temperature and time for hybrid tea rose variety 'Valencia', followed by drying at $50^{\circ} \mathrm{C}$ for 24 hours. And also silica gel is found to be a better embedding material for drying of rose as compared to boric acid.

\section{References}

I. Bintory, M.A, Seetharamu, G.K, Munikrishnappa, P.M, Ramegowda, G.K. \& Basavaraj, G. (2015). Evaluation of the Colour of Dried Dutch Rose Flowers Using a Colorimeter. Journal of Horticulture $2,157$.

2. Smith, R.C. (1993). Methods of preserving flowers. NDSU Extension Service, N. Dakote State University of Agri. and Applied Science, USA.

3. Singh, A. (2004). Study of dehydration of Zinnia. Indian Journal of Plant Physiology 9(4), 383-387.

4. Bhalla, R. \& Sharma. B (2002). Dry flowers status, scope and potential. In: Choudhary M L et al., (eds). Production and Management of Flower Crops. Division of Floriculture and Landscaping, IARI, New Delhi, pp. I62I7I.

5. Bhutani, J.C. (1993). Economic potential of dried flowers. Agricultural Marketing 36(I), 43-46.

6. Dilta, B.S., Sharma, B.P., Baweja, H.S. \& Kashyap, B. (20II). Flower drying techniques - a review. International Journal of Farm Sciences I(2), I-16.

7. Prasad, J.K., Pal, P.K. \& Voleti, S.R. (1997). Drying of flowers: an upcoming industry. Floriculture Today pp. 20-23.

8. Datta, S.K. (1997). Dehydration of flowers and foliage and floral craft. NBRI Bulletin No 3 , EBIS, NBRI, Lucknow, p. 20.

9. Bhattacharjee, S.K. \& De, L.C. (2003). Dried flowers and plant parts. In: Advanced Commercial Floriculture. Avishkar Publishers, Jaipur, pp 162-173.

Io. Pandey, P.H. (200I). Principles and Practices of Postharvest Technology. Kalyani Publishers, Ludhiana.

II. Bhutani. J.C. (1990). Capturing nature, a way with flower "Everlastings". Indian Horticulture. 34(4), 15-19. 